\title{
Factors Responsible for the Diagnostic Delay in Oral Cancer Patients: A Hospital Based Sociodemographic Study in Kolkata
}

\author{
Pramitasri Bhattacharyya, ${ }^{1}$ Dwaipayan Mukherjee, ${ }^{2}$ Snehasis Barman, ${ }^{3}$ Tushar Kanti Dey, ${ }^{4}$ Jaydip Biswas $^{5}$
}

\begin{abstract}
Introduction
Oral cancer is a challenging health problem globally. Delay in diagnosis is an important factor in determining the outcome of the disease. It is a major determinant of mortality and morbidity of oral cancer patients. Present observational study was conducted with the objective of finding the factors responsible for delay in diagnosis of oral cancer in patients.

Materials and Methods

Hospital based observational study where patient register was used as data source from 15th Nov, 2013-15th Jan, 2014.

$\underline{\text { Results }}$

Among the causes for delay in reporting to hospital, financial constraint (84\%) and illiteracy (56.5\%) have been found to contribute the most. The risk of primary delay is 3.53 times more among illiterate in comparison with literate. Age, gender, stage of cancer, religion, caste, tobacco use and delayed referral from the first physician were the other factors found to be significant in relation to primary delay.

Discussion

Early diagnosis is a major factor for favorable outcome of a disease and several factors hinder early diagnosis. Some of these factors can be easily modified through Information, Education and Communication (IEC).

Conclusion

Some important factors that lead to delay are identified and some of them are preventable. So, IEC regarding cancer among general population will not only provide knowledge to them, but also will break myths regarding cancer and reduce the burden of disease. These identified predictors of delay may be used for designing an educational intervention program for patients with oral cancers.

Kevwords
\end{abstract}

$\underline{\text { ABSTRACT }}$

Oral Cancer; Primary Delay; Diagnosis

$\mathrm{O}$ ral cancer has one of the lowest survival rates worldwide, which remains unaltered despite recent therapeutic advances. Unfortunately, half of these neoplasms are diagnosed at stage III or IV with 5-year survival rates ranging from $20 \%$ to $50 \%$. ${ }^{1}$ Delay in the diagnosis is an important and fatal factor in determining the outcome of the disease. It is a major determinant of mortality and morbidity of oral cancer patients. This is more so for resource-poor countries like India, where the prevalence of oral cancer is very high.

Early detection, by reducing the delay in diagnosis, has widely been recognised as the cornerstone in improving the chances of survival in oral cancer.
Identification and elimination of the causes that lead to delay in the diagnosis may help people fight cancer by early identification of the disease. This would make the management less expensive and ensure better survival

1 - Institute of Health and Family Welfare, Kolkata

2 - Department of ENT, KPC Medical College, Kolkata

3 - Chatuskon Daycare Centre, Uttarpara, West Bengal

4 - Dept. of Epidemiology, AIIHPH, Kolkata

5 - Chittaranjan National Cancer Institute, Kolkata

Corresponding author:

Dr Snehasis Barman

email: burmansn74@gmail.com 
with less deformity.

\section{Materials and Methods}

The hospital based observational study was conducted from 1st August, 2013 to 31st March, 2014 using data collected from 15th November, 2013 to 14th January, 2014 at a specialised cancer hospital in Kolkata to assess the health care seeking behavior of Oral Cancer patients with special reference to primary delay in diagnosis and also to identify the socioeconomic factors associated with delay in diagnosis. Primary delay is defined as the delay between the appearance of first symptom and the seeking of medical advice. ${ }^{2}$

During the period of data collection from 15th November to 15th January, 441 patients of oral cancer attended the hospital. Hospital register was used as the sampling frame to select the study population. Out of the seven days of a week, odd days in odd number of weeks and even days in even number of weeks (Monday, Wednesday, Friday in weeks 1, 3, 5 and Tuesday, Thursday, Saturday in weeks 2,4) were selected for collection of data. The diagnosed patients of oral cancer attending the hospital on these scheduled prefixed days during the period of data collection were considered for the study. Patients who were non-cooperative (exhausted due to prolonged waiting, stressed with the thought of having cancer) or were physically unfit to respond to the interview (with bleeding, tracheostomy, unable to open mouth properly) were excluded from this study, as also the terminally ill patients.

The patients were examined clinically, relevant medical records were reviewed and the disease was staged after getting informed consent from them. The patients were interviewed with a pre-designed, pretested, semi-structured questionnaire.

Considering the prevalence of primary delay of $>3$ months (90 Days) in attending the Oncology Department to be $20 \%,{ }^{3}$

That is $\mathrm{p}=0.20(\mathrm{p}=$ prevalence $)$

Then, $\mathrm{q}=1-0.20=0.80$ (where, $\mathrm{q}=1-\mathrm{p}$ )

Taking 95\% level of confidence and $10 \%$ allowable error (absolute $)=(d)$, using the formula ${ }^{4}$ for $\mathrm{Z}$ test, $\mathrm{n}=$ $(\mathrm{z} 1-\alpha / 2)^{2} \mathrm{x} \mathrm{pxq} / \mathrm{d}^{2}=(1.96)^{2} \mathrm{x} 0.2 \mathrm{x} 0.8 /(0.10)^{2}=61.44 \sim 62$
[Where, $p=$ prevalence, $q=(1-p), d=$ allowable error (absolute), $\mathrm{n}=$ sample size,

$\mathrm{z}$ =follows normal distribution with mean 0 and variance $1, \alpha=$ level of significance]

Taking Design Effect $(62 \times 3)=186$ is the minimum sample size and hence 200 diagnosed oral cancer cases were included in this study.

To assess the factors related to primary delay, data were analyzed by dividing the patients into two groups; e.g., patients having primary delay $>90$ days ( 3 months was the Median) and primary delay $\leq 90$ days.

Statistical Analysis was performed with help of Epi Info ${ }^{\circledR}$ 3.5.3 software of the Centers for Disease Control and Prevention (CDC). Chi-square test was used to test the association of different study variables. Z-test was used to test the significant difference between two proportions. Odds Ratio (OR) with 95\% Confidence Interval (CI) was calculated to measure the different risk factors. Multiple Logistic Regression was used for multivariate analysis. Confidence Intervals were at 95 percent level, $\mathrm{p}<0.05$ was considered statistically significant.

\section{Results}

The present study is an observation of factors influencing delay (primary) in the diagnosis of oral cancer patients. This study was conducted with a sample size of 200 diagnosed cases of oral cancer attending a Specialised Cancer Hospital in Kolkata from 15th November, 2013 to 14th January, 2014.

The median value for primary delay of the patients was 90 days. To find the factors related to primary delay we have analyzed data by dividing the patients into two groups: patients having primary delay $>90$ days and primary delay $\leq 90$ days. In this study the primary delay was $>90$ days in $42.5 \%$ of patients and in $57.5 \%$ the primary delay was $\leq 90$ days. The median age (mean \pm standard deviation) of the patients was 56 years with age range of 25 - 86 years. People in the age group of 45-54 years were affected most (37\%) and the least affected age group was 25 -34yrs $(2.5 \%)$. (Table I)

The risk of primary delay was 2.60 times more for 
Table I : Age distribution of the patients

\begin{tabular}{|c|c|c|}
\hline $\begin{array}{c}\text { AGE } \\
\text { GROUP (IN } \\
\text { YEARS) }\end{array}$ & NUMBER & PERCENTAGE \\
\hline $25-34$ & 5 & $2.5 \%$ \\
\hline $35-44$ & 32 & $16.0 \%$ \\
\hline $45-54$ & 74 & $37.0 \%$ \\
\hline $55-64$ & 52 & $26.0 \%$ \\
\hline $65-74$ & 23 & $11.5 \%$ \\
\hline$>74$ & 14 & $7.0 \%$ \\
\hline TOTAL & $\mathbf{2 0 0}$ & $\mathbf{1 0 0 . 0} \%$ \\
\hline
\end{tabular}

the patients with age $>50$ years as compared with the patients with age $\leq 50$ years and the risk was significant. (Table II) There was significant association between gender and primary delay of the patients. It was noticed that the risk of primary delay was 1.89 times more for females in comparison with males. The risk was significant $[\mathrm{OR}=1.89, \mathrm{p}=0.03]$ (Table III)

In this study most of the patients $(52.0 \%)$ were found in advanced stage of oral cancer, Stage-III. There was significant association between stage of cancer and primary delay of the patients $(\mathrm{p}=0.00001)$. (Table IV) Level of education and primary delay of the patients $(p=0.003)$ shows significant association too. The risk

Table II : Age and primary delay

\begin{tabular}{|c|c|c|c|}
\hline \multirow{2}{*}{$\begin{array}{c}\text { AGE } \\
\text { GROUP } \\
\text { (IN } \\
\text { YEARS) }\end{array}$} & \multicolumn{2}{|c|}{ DELAY } & \multirow{2}{*}{ TOTAL } \\
\cline { 2 - 3 } & $>90$ days & $\leq 90$ days & \\
\hline$>50$ & $\begin{array}{c}58 \\
(52.7 \%)\end{array}$ & $\begin{array}{c}52 \\
(47.3 \%)\end{array}$ & $\begin{array}{c}110 \\
(100.0 \%)\end{array}$ \\
\hline \multirow{2}{*}{$\leq 50$} & 27 & 63 & 90 \\
$(30.0 \%)$ & $(70.0 \%)$ & $(100.0 \%)$ \\
\hline TOTAL & $\mathbf{8 5}$ & $\mathbf{1 1 5}$ & $\mathbf{2 0 0}$ \\
& $(\mathbf{4 2 . 5} \%)$ & $\mathbf{( 5 7 . 5 \% )}$ & $\mathbf{( 1 0 0 . 0 \% )}$ \\
\hline
\end{tabular}

Table III : Gender and primary delay

\begin{tabular}{|c|c|c|c|}
\hline \multirow{2}{*}{ GENDER } & \multicolumn{2}{|c|}{ DELAY } & \multirow{2}{*}{ TOTAL } \\
\hline & $>90$ days & $\leq 90$ days & \\
\hline Female & $\begin{array}{c}34 \\
(53.1 \%)\end{array}$ & $\begin{array}{c}30 \\
(46.9 \%)\end{array}$ & $\begin{array}{c}64 \\
(100.0 \%)\end{array}$ \\
\hline Male & $\begin{array}{c}51 \\
(37.5 \%)\end{array}$ & $\begin{array}{c}85 \\
(62.5 \%)\end{array}$ & $\begin{array}{c}136 \\
(100.0 \%)\end{array}$ \\
\hline TOTAL & $\begin{array}{c}85 \\
(42.5 \%)\end{array}$ & $\begin{array}{c}115 \\
(57.5 \%)\end{array}$ & $\begin{array}{c}200 \\
(100.0 \%)\end{array}$ \\
\hline
\end{tabular}

of primary delay is 3.53 times more among illiterate in comparison with literate and the risk was significant $[\mathrm{OR}=3.53(1.95,6.38) ; \mathrm{p}=0.000002]$. (Table V) 97.5\% of the study population had no knowledge at all about

Table IV : Comparison of the primary delay in relation to the stage of cancer

\begin{tabular}{|c|c|c|c|}
\hline \multirow{2}{*}{$\begin{array}{c}\text { COMPOSITE } \\
\text { STAGE }\end{array}$} & \multicolumn{2}{|c|}{ DELAY IN DAYS } & \multirow{2}{*}{ TOTAL } \\
\hline & $>90$ & $\leq 90$ & \\
\hline $\begin{array}{c}\text { Stage-I } \\
\text { (No. of patients) } \\
\%\end{array}$ & $\begin{array}{c}1 \\
(11.1 \%)\end{array}$ & $\begin{array}{c}8 \\
(88.9 \%)\end{array}$ & $\begin{array}{c}9 \\
(100.0 \%)\end{array}$ \\
\hline $\begin{array}{c}\text { Stage-II } \\
\text { (No. of patients) } \\
\%\end{array}$ & $\begin{array}{c}5 \\
(6.7 \%)\end{array}$ & $\begin{array}{c}70 \\
(93.3 \%)\end{array}$ & $\begin{array}{c}75 \\
(100.0 \%)\end{array}$ \\
\hline $\begin{array}{c}\text { Stage-III } \\
\text { (No. of patients) } \\
\%\end{array}$ & $\begin{array}{c}69 \\
(66.3 \%)\end{array}$ & $\begin{array}{c}35 \\
(33.7 \%)\end{array}$ & $\begin{array}{c}104 \\
(100.0 \%)\end{array}$ \\
\hline $\begin{array}{c}\text { Stage-IV } \\
\text { (No. of patients) } \\
\%\end{array}$ & $\begin{array}{c}10 \\
(83.3 \%)\end{array}$ & $\begin{array}{c}2 \\
(16.7 \%)\end{array}$ & $\begin{array}{c}12 \\
(100.0 \%)\end{array}$ \\
\hline $\begin{array}{c}\text { TOTAL } \\
\text { (NO. OF } \\
\text { PATIENTS) \% }\end{array}$ & $\begin{array}{c}85 \\
(42.5 \%)\end{array}$ & $\begin{array}{c}115 \\
(57.5 \%)\end{array}$ & $\begin{array}{c}200 \\
(100.0 \%)\end{array}$ \\
\hline
\end{tabular}


Table V : Level of education and primary delay

\begin{tabular}{|c|c|c|c|}
\hline \multirow{2}{*}{$\begin{array}{c}|c| \\
\text { LEVEL OF } \\
\text { EDUCATION }\end{array}$} & \multicolumn{2}{|c|}{ DELAY IN DAYS } & \multirow{2}{*}{ TOTAL } \\
\cline { 2 - 3 } & $>90$ & $\leq 90$ & \multicolumn{1}{|c|}{} \\
\hline $\begin{array}{c}\text { Illiterate } \\
\text { (No. of patients) }\end{array}$ & $\begin{array}{c}49 \\
(60.5 \%)\end{array}$ & $\begin{array}{c}32 \\
(39.5 \%)\end{array}$ & $\begin{array}{c}81 \\
(100.0 \%)\end{array}$ \\
\hline $\begin{array}{c}\text { Literate } \\
\text { (No. of patients) }\end{array}$ & $\begin{array}{c}36 \\
(30.3 \%)\end{array}$ & $\begin{array}{c}83 \\
(69.7 \%)\end{array}$ & $\begin{array}{c}119 \\
(100.0 \%)\end{array}$ \\
\hline $\begin{array}{c}\text { TOTAL (NO. OF } \\
\text { PATIENTS)\% }\end{array}$ & $\begin{array}{c}\mathbf{8 5} \\
(\mathbf{4 2 . 5} \%)\end{array}$ & $\begin{array}{c}\mathbf{1 1 5} \\
(\mathbf{5 7 . 5} \%)\end{array}$ & $\begin{array}{c}\mathbf{2 0 0} \\
(\mathbf{1 0 0 . 0} \%)\end{array}$ \\
\hline
\end{tabular}

oral cancer. (Table VI)

There was significant association between referral from the first physician and delay in patients attending the Specialized Cancer Care Hospital (Chi-square test $=12.04, p=0.03$ ). (Table VII) Among the causes of delay in reporting to the Specialized

Table VI : Idea about cancer $(n=200)$

\begin{tabular}{|c|c|c|}
\hline $\begin{array}{c}\text { IDEA ABOUT } \\
\text { CANCER }\end{array}$ & NUMBER & PERCENTAGE \\
\hline $\begin{array}{c}\text { Ill-fated } \\
\text { ulcer }\end{array}$ & 163 & $1 \%$ \\
\hline $\begin{array}{c}\text { Small mouth } \\
\text { treatment }\end{array}$ & 80 & $81.5 \%$ \\
\hline $\begin{array}{c}\text { Avoidance due } \\
\text { to fear }\end{array}$ & 20 & $10 \%$ \\
\hline $\begin{array}{c}\text { Lack of } \\
\text { knowledge }\end{array}$ & 195 & $97.5 \%$ \\
\hline Others & 7 & $3.5 \%$ \\
\hline
\end{tabular}

Table VII : Referral from the first physician and primary delay

\begin{tabular}{|c|c|c|c|}
\hline \multirow{2}{*}{$\begin{array}{c}|2| \\
\text { REFERRAL } \\
\text { FROM 1ST } \\
\text { PHYSICIAN }\end{array}$} & \multicolumn{2}{|c|}{ DELAY IN DAYS } & \multirow{2}{*}{ TOTAL } \\
\cline { 2 - 3 } & $>90$ & $\leq 90$ & \multicolumn{1}{|c|}{} \\
\hline Yes & $\begin{array}{c}36 \\
(39.6 \%)\end{array}$ & $\begin{array}{c}55 \\
(60.4 \%)\end{array}$ & $\begin{array}{c}91 \\
(100.0 \%)\end{array}$ \\
\hline \multirow{2}{*}{ No } & $\begin{array}{c}53 \\
(48.6 \%)\end{array}$ & $\begin{array}{c}56 \\
(51.4 \%)\end{array}$ & $\begin{array}{c}109 \\
(100.0 \%)\end{array}$ \\
\hline \multirow{2}{*}{ TOTAL } & $\begin{array}{c}\mathbf{8 9} \\
(\mathbf{4 4 . 5} \%)\end{array}$ & $\begin{array}{c}\mathbf{1 1 1} \\
(\mathbf{5 5 . 5} \%)\end{array}$ & $\begin{array}{c}\mathbf{2 0 0} \\
(\mathbf{1 0 0 . 0} \%)\end{array}$ \\
\hline
\end{tabular}

Cancer Care Centre, financial constraint is the main cause $(84 \%)$ followed by operational delay $(70 \%)$ (Table VIII) Significant association between monthly family

Table VIII : Cause of delay in reporting to Specialized Cancer Care Hospital with relation to literacy

\begin{tabular}{|c|c|c|c|}
\hline & & & \\
\hline Financial & $(43.5 \%)$ & $(56.5 \%)$ & $(84 \%)$ \\
\hline Operational & $\begin{array}{c}58 \\
(41.4 \%)\end{array}$ & $\begin{array}{c}82 \\
(58.6 \%)\end{array}$ & $\begin{array}{c}140 \\
(70 \%)\end{array}$ \\
\hline Disbelief & $\begin{array}{c}4 \\
(33.3 \%)\end{array}$ & $\begin{array}{c}8 \\
(66.7 \%)\end{array}$ & $\begin{array}{c}12 \\
(6 \%)\end{array}$ \\
\hline Belief & 14 & 31 & 45 \\
\hline in other & $(31.1 \%)$ & $(68.9 \%)$ & $(22.5 \%)$ \\
\hline medicine & $\begin{array}{c}58 \\
\text { Ignorance }\end{array}$ & $\begin{array}{c}75 \\
(43.6 \%)\end{array}$ & $\begin{array}{c}13 \% \\
(56.4 \%)\end{array}$ \\
\hline Others & $\begin{array}{c}402.5 \%) \\
(39.2 \%)\end{array}$ & $\begin{array}{c}102 \\
(60.8 \%)\end{array}$ \\
\hline
\end{tabular}


Table IX : Monthly family income and primary delay

\begin{tabular}{|c|c|c|c|}
\hline \multirow{2}{*}{$\begin{array}{c}\text { MONTHLY } \\
\text { FAMILY } \\
\text { INCOME } \\
\text { (IN RS.) }\end{array}$} & \multicolumn{2}{|c|}{ NO. OF PATIENTS } & \multirow{2}{*}{ TOTAL } \\
\cline { 2 - 3 } & $\begin{array}{c}\text { Delay in } \\
\text { days }>90\end{array}$ & $\begin{array}{c}\text { Delay in } \\
\text { days } \leq 90\end{array}$ \\
\hline & $\begin{array}{c}66 \\
(69.5 \%)\end{array}$ & $\begin{array}{c}29 \\
(30.5 \%)\end{array}$ & $\begin{array}{c}95 \\
(100.0 \%)\end{array}$ \\
\hline$>2000$ & $\begin{array}{c}19 \\
(18.1 \%)\end{array}$ & $\begin{array}{c}86 \\
(81.9 \%)\end{array}$ & $\begin{array}{c}105 \\
(100.0 \%)\end{array}$ \\
\hline TOTAL & $\begin{array}{c}\mathbf{8 5} \\
(\mathbf{4 2 . 5} \%)\end{array}$ & $\begin{array}{c}\mathbf{1 1 5} \\
(\mathbf{5 7 . 5} \%)\end{array}$ & $\begin{array}{c}\mathbf{2 0 0} \\
(\mathbf{1 0 0 . 0} \%)\end{array}$ \\
\hline
\end{tabular}

income and primary delay of the patients was noted. The risk of primary delay was 10.30 times more among the patients having monthly family income $\leq$ Rs.2000, in comparison with the patients having monthly family income $>$ Rs.2000 and the risk was significant $[\mathrm{OR}=$ $10.30(5.31,19.96) ; p=0.000001]$. (Table IX)

Under multivariate analysis, Logistic Regression (Table $\mathrm{X}$ ) showed that the risk of primary delay was 1.66 times for age $>50[\mathrm{OR}=1.66(1.82,3.38) ; \mathrm{p}=0.015]$, 9.04 times for patients with monthly family income < Rs. $2000[\mathrm{OR}=9.04(4.39,18.61) ; \mathrm{p}=0.00001], 2.54$ times for illiterate $[\mathrm{OR}=2.54(1.25,5.18) ; \mathrm{p}=0.009]$ and 2.14 times for females $[\mathrm{OR}=2.14(1.02,4.48) ; \mathrm{p}=0.00001]$.

\section{Discussion}

Over 2,75,000 of Oral Cancer cases are diagnosed yearly worldwide. ${ }^{5}$ About $40 \%$ of all malignancies are oral cancer in Southeast Asia. ${ }^{6}$ Men are more affected due to tobacco use and sunlight exposure from

\section{Table X : Result of Multivariate Analysis}

$[B=$ Beta or Regression Coefficient, SE = Standard Error, Wald = Wald Statistic for Testing Regression Coefficient, $d f=$ Degrees of Freedom required to calculate p-value, Sig $=$ Level of Significance or p-value, $R=$ Logistic Regression, $\operatorname{Exp}(B)=$ Exponential of Beta to estimate Odds Ratio for Risk, CI = Confidence Interval]

\begin{tabular}{|c|c|c|c|c|c|c|c|c|c|}
\hline \multirow{2}{*}{ VARIABLES } & \multirow{2}{*}{ B } & \multirow{2}{*}{ S.E. } & \multirow{2}{*}{ WALD } & \multirow{2}{*}{ DF } & \multirow{2}{*}{ SIG } & \multirow{2}{*}{$\mathbf{R}$} & \multirow{2}{*}{$\mathbf{E X P}(\mathbf{B})$} & \multicolumn{2}{|c|}{$\begin{array}{l}95 \% \text { CI FOR EXP } \\
\text { (B) }\end{array}$} \\
\hline & & & & & & & & LOWER & UPPER \\
\hline Age & 0.5112 & 0.3615 & 2.0001 & 1 & 0.01573 & 0.0005 & 1.6674 & 1.8210 & 3.3864 \\
\hline Sex & 0.7609 & 0.3779 & 4.0531 & 1 & 0.0441 & 0.0868 & 2.1402 & 1.0203 & 4.4891 \\
\hline Religion & 0.1324 & 0.3937 & 0.1130 & 1 & 0.7367 & 0.0000 & 1.1415 & 0.5277 & 2.4693 \\
\hline Illiteracy & 0.9347 & 0.3625 & 6.6500 & 1 & 0.0099 & 0.1306 & 2.5464 & 1.2514 & 5.1815 \\
\hline Family income & 2.2022 & 0.3683 & 35.7616 & 1 & 0.00001 & 0.3518 & 9.0448 & 4.3948 & \\
\hline Constant & 2.4326 & 0.3995 & 37.0860 & 1 & 0.00001 & & & & \\
\hline
\end{tabular}


outdoor occupation. Chewing or smoking of tobacco as specified earlier combined with unhealthy oral habits, poor nutritional status, weak financial standing, difficult access to medical care add to the burden of oral cancer in India. India tops the list in reported oral cancer cases.

The prevalence rate of Oral Cancer in India is 12.8 (male) and 7.5 (female) / 1, 00,000 populations. ${ }^{8}$ Oral cancer prevalence rate in Kolkata is 8 (total), 12.10 (male), 4.71 (female) / 100,000 population. ${ }^{5,9}$ In 2010, around 5,55,000 people died of oral cancer in India.

Delay in diagnosis is undoubtedly a major determinant of mortality of oral cancer patients and also adds to its morbidity. The factors that induce delay (primary) are multiple and varied. Present observational study was conducted with the objective of studying the factors influencing delay of oral cancer patients as well as their health seeking behaviour with a hope to modify that behaviour. But in Eastern India adequate statistical modelling for multivariate data has often not been done to elicit the most important factors that lead to delay in diagnosis in oral cancer patients.

Many factors are found to be significantly associated with the delay. Many of these factors are found to be interrelated and they can confound the results. So, multivariate analysis has also been done to calculate unadjusted Odds Ratio. In this hospital based study, the median primary delay was 90 days. Similar result was found in retrospective - descriptive study of Jafari et $\mathrm{al}^{3}$ (2013); Willams et $\mathrm{al}^{10}$ (1981) and Elwood et al ${ }^{11}$ (1985) also have seen in their study that cut off value for primary delay in diagnosis was 3 months. According to the present study $57.5 \%$ patients came within 3 months and $42.5 \%$ after 3 months.

Agarwal et al ${ }^{12}(2011)$ noticed in his study that 39\% patients came in 2 months, whereas $61 \%$ came at around 4.5 months. Similarity is also found when it was seen that maximum patients came in stage III( $52 \%)$, stage IV $(6 \%)$ according to the present study and Agarwal et al ${ }^{12}(2011)$ noticed that $61 \%$ patient presented in late stage(III, IV). Squamous Cell Carcinoma (SCC) is the most common type of oral cancer noticed in almost all the studies done on oral cancer. ${ }^{9}$

A very clear gender discrimination is seen where it was found that among females $53.1 \%$ presented late, whereas male contributed to only $37.5 \%$ in late presentation. According to some other studies same gender inclination was noticed. ${ }^{12,13}$

As buccal mucosa cancer constitutes majority $(42.5 \%)$ of cases and the common symptoms are ulcer and pain (49.6\%), a non-healing ulcer and pain were the most common early presenting symptoms of oral cancer. ${ }^{2,14}$ If the patients were aware of these symptoms they would consider them serious enough to perform self-examination. This can be the basis of an educational programme. Therefore, one cannot accept that late detection of the majority of cases of oral cancer is inevitable. Similar studies also agreed with the same., ${ }^{2,10}$

Regarding literacy it was seen that in the delayed group ( $>90$ days), $56.4 \%$ were illiterate and $43.6 \%$ were literate. ${ }^{9}$ This study found that in the delayed group of $>90$ days, $57.5 \%$ were illiterate and $42.5 \%$ were literate. These two values are very close to each other.

Regarding Socioeconomic (SE) status 69.5\% of lower class fell in delay $>90$ days and $30.5 \%$ in delay $\leq$ 90 days. On the contrary only $18.1 \%$ of high SE class fell in Delay $>90$ days and $81.9 \%$ fell in Delay $\leq$ 90days. The results are similar in a few studies ${ }^{9,15}$ whereas, some other studies have found no significant effect of socioeconomic status or literacy on treatment delay. ${ }^{11,12}$ Thus the literacy and socio-demographic status is strongly associated with delay.

The proportion of delay was significantly higher in never married (77.8\%) and widows (53.8\%).

The correlation observed between primary and secondary delay shows that there is a large scope for educating primary care physicians and dentists for an early referral of patients. In a study published from the UK, it was reported that $70 \%$ of medical and dental general practitioners were unable to recognize carcinoma of the mouth. ${ }^{16}$ In his study, Kumar et al (1993) reported that $22 \%$ of patients delayed reporting to hospital for more than 6 months after seeing their family doctor. ${ }^{17}$

Treatment by Homeopathy was $18 \%$ and $3 \%$ received no treatment despite attending a clinician. The use of alternative medicine and the treatment delay caused by that has been well documented in the past. ${ }^{18,19,20}$ In our study the consultation of unqualified local practitioners / alternative medicine could be attributed 
to the sheer ignorance and lack of primary health care facilities as most of such consultations were sought by the individuals with low literacy levels or who had no access to a registered practitioner or who were unaware of their probable diagnosis.

Thus, we would like to comment that illiteracy, low socio-economic status and female gender are significantly associated with primary delay in oral cancer patients in our population. Similarly, unavailability of primary qualified physician also seems to be contributory towards this delay. These identified predictors of delay may be used for designing an educational intervention program for patients with oral cancers.

\section{Conclusion}

Among the causes for delay in reporting to hospital, financial constraint (84\%) and illiteracy (56.5\%) have been found to contribute the most. $97.5 \%$ of the patients had no knowledge about cancer whatsoever and $59 \%$ of the literate were lacking proper knowledge about cancer.

Age, gender, stage of cancer, literacy, religion, caste, tobacco use and delayed referral from the first physician were the other factors found to be significant in relation to primary delay. Difficulty in access to health care facilities and inadequacy of knowledge of cancer screening on part of the doctor and ignorance of patient are major contributory factors for the delay in the diagnosis of oral cancer as found in this study.

\section{References}

1. Centelles PV, Seoane-Romero JM, Gómez I, Diz-Dios P, de Melo NS, Seoane J. Timing of Oral Cancer Diagnosis: Implications for Prognosis and Survival, Ogbureke KUE (Ed.), Oral Cancer, 2012. ISBN: 978-953-51-0228-1, InTech, Available from: http://www.intechopen.com/books/oral-cancer/timing-of-oralcancer-diagnosis-implications-for-prognosis-andsurvival

2. Kumar S, Heller RF, Pandey U, Tewari V, Bala N, Oanh KT.Delay in presentation of oral cancer: a multifactor analytical study. Natl Med J India 2001;14(1):13-7

3. Jafari A, Najafi SH, Moradi F, Kharazifard MJ, Khami MR. Delay in the Diagnosis and Treatment of Oral Cancer. J Dent (Shiraz). 2013; 14(3): 146-50

4. International Agency for Research on Cancer: WHO. Indian cancer statistics, a model to be followed. Press Release $\mathrm{N}^{\circ} 210$. 28 March,2012:1

5. Blackwell M, Petersen PE. Strengthening the prevention of oral cancer: the WHO perspective. Community Dentistry of Oral Epidemiology 2005; 33:397-9

6. Priebe SL, Alekseju ${ }^{-}$niene' J, Dharamsi S , Zed C. Oral cancer and cultural factors in Asia. Can J Dent Hygiene 2008; 2008; 42(6):289-93

7. National Institute of Cancer Prevention and Research:Cancer Blog. Rise of oral Cancer and treatment facilities in India: June 1,2013

8. Sinha R, Anderson DE, McDonaldSS, Greenwald P. Cancer risk and diet in India. J Postgrad Med. 2003; 49(3):222-8

9. Marimuthu P, Chakraborty S, Agarwal S, Manoharan N, Chatterjee M. Trends of Cancer Prevalence in Some Districts of West Bengal. Asian Pac J Cancer Prev.2002;3:239-42

10. Williams RG. The early diagnosis of carcinoma of the mouth. Ann R Coli Surg Engl.1981;63:423-5

11. Elwood JM, Gallagher RP. Factors inIluencing early diagnosis of cancer of the oral cavity. Can Med Assoc J. 1985; 133:651 6

12. Agarwal AK, Sethi A, Sareen D, Dhingra S. Treatment delay in oral and oropharyngeal cancer in our population: The role of socio-economic factors and health-seeking behaviour. Indian J Otolaryngol Head Neck Surg 2011;63:145-50

13. Yu T, Wood RE, Tenenbaum HC. Delays in Diagnosis of Head and Neck Cancers. JCDA • www.cda-adc.ca/jcda 2008; 74(1):61-61c. Acccessed www.cda-adc.ca/jcda/vol-74/ issue-1/61.html in Jan, 2014

14. Sankaranarayanan R. Oral cancer in India: An epidemiologic and clinical review. Oral Surg Oral Med Oral Pathol.1990;69:325-30

15. Kumar S, Hellar RF, Pandey U, Tewari V, Bala N, Oanh KTH. Delay in presentation of oral cancer; a multifactor analytic study. Natl Med J India 2001; 14(1):13-7

16. Stell PM, McCormick MS. Prognosis in cancer of the head and neck. In: Taylor I (ed) Progress in surgery. Volume 2. Edinburgh:Churchill Livingstone, 1987:9.

17. Kumar S, Agarwal SP, Gupta CK. Investigation of factors causing delay in the treatment of oral mucosal cancer. Indian J Oral Maxilliofac Surg. 1993; 8:41-7

18. Carvalho AL, Pintos J, Schlecht NF, Oliveira BV, Fava AS, Curado MP et al. Predictive factors for diagnosis of advancedstage squamous cell carcinoma of the head and neck. Arch Otolaryngol Head Neck Surg. 2002; 128(3):313-8

19. Davis GE, Bryson CL, Yueh B, McDonell MB, Micek MA, Fihn SD. Treatment delay associated with alternative medicine use among veterans with head and neck cancer. Head Neck 2006; 28(10):926-931. doi: 10.1002/hed.20420

20. Ernst E, Cassileth BR. The prevalence of complementary/ alternative medicine in cancer: a systematic review. Cancer.1998; 83(4):777-782. doi: 10.1002/(SICI)10970142(19980815)83:4<777::AID-CNCR22>3.0.CO;2-O. 